\title{
Ocean acidification studies and the uncertainties relevance on measurements of marine carbonate system properties
}

\author{
Adriana Rodrigues Perretti ${ }^{1,5 *}$, Ana Cecília Rizzatti de Albergaria-Barbosa ${ }^{2,5}$, Rodrigo Kerr ${ }^{3,5}$, \\ Leticia Cotrim da Cunha ${ }^{4,5}$
}

\author{
${ }^{1}$ Centro de Estudo do Mar da Universidade Federal do Paraná - UFPR \\ (Av. Beira-mar, s/n. Caixa Postal: 61 - Pontal do Paraná - PR - 83255-000 - Brazil) \\ ${ }^{2}$ Instituto de Geociências da Universidade Federal da Bahia - UFBA \\ (Rua Barão de Jeremoabo, s/n - Ondina - Salvador - BA - 40170-115 - Brazil) \\ ${ }^{3}$ Instituto de Oceanografia da Universidade Federal do Rio Grande - FURG \\ (Av. Itália, km 8 - Bairro Carreiros - Rio Grande - RS - 96203-900 - Brazil) \\ ${ }^{4}$ Faculdade de Oceanografia do Estado do Rio de Janeiro - UERJ \\ (Rua São Francisco Xavier, 524 - Rio de Janeiro - RJ - 20550-900 - Brazil) \\ ${ }^{5}$ Brazilian Ocean Acidification Network \\ (BrOA - www.broa.furg.br, broa@furg.br) (Rio Grande - RS - 96203-900 - Brazil) \\ *Corresponding author: adriana.perretti@ufpr.br
}

The global ocean has a key role on the Earth's climate system. It possesses a direct connection with the atmospheric gases, including the greenhouses, allowing exchanges between those compartments and oceanic storage of carbon. Through the years, this exchange of gases occurred based on gas equilibrium between ocean and atmosphere. After the Industrial Revolution, human activities have increased the emissions of greenhouse gases, mainly carbon dioxide $\left(\mathrm{CO}_{2}\right)$, which changed the atmospheric concentration from $\sim 280 \mathrm{ppm}$ of $\mathrm{CO}_{2}$ to values as high as $391 \mathrm{ppm}$ between c.a. 1750 and 2011 (Ciais et al., 2013). Recently, the measured $\mathrm{CO}_{2}$ atmospheric values are ranging near or above $400 \mathrm{ppm}$, as recorded by the Mauna Loa observatory, in Hawaii (daily $\mathrm{CO}_{2}$ measurements information available on www. scripps.ucsd.edu). A regional study in the south-southeast Brazilian continental shelf agrees with this value, which has measured an average of $396.7 \pm 2.5 \mathrm{ppm}$ in the atmosphere during the spring of October 2014 (Kerr et al., 2016). This enhancement is reflected in the ocean, which has absorbed about $25 \%$ to $30 \%$ of the anthropogenic atmospheric $\mathrm{CO}_{2}$ emissions (Sabine and Tanhua, 2010; Le Quére et al., 2016). The $\mathrm{CO}_{2}$ uptake by the oceans directly affects the seawater chemistry and marine biogeochemical processes, impacting both the ecosystems and their respective biota (Doney et al., 2009).

Atmospheric $\mathrm{CO}_{2}$ can be transferred to seawater through the air-sea interface, where it dissolves and reacts with $\mathrm{H}_{2} \mathrm{O}$ forming the carbonic acid $\left(\mathrm{H}_{2} \mathrm{CO}_{3}\right)$. The $\mathrm{H}_{2} \mathrm{CO}_{3}$ is a weak acid and promptly suffers two dissociation

Submitted on: 4/June/2017

Approved on: 11/March/2018

http://dx.doi.org/10.1590/S1679-87592018000706602 processes that release protons $\left(\mathrm{H}^{+}\right)$: the first one originates bicarbonate ion $\left(\mathrm{HCO}_{3}^{-}\right)$; and the second one, carbonate ion $\left(\mathrm{CO}_{3}{ }^{2-}\right)$ (Figure 1). The term total dissolved inorganic carbon (DIC) is the sum of the three main inorganic forms of $\mathrm{CO}_{2}$ in seawater (i.e., $\mathrm{CO}_{2}{ }^{*}, \mathrm{HCO}_{3}^{-}$and $\mathrm{CO}_{3}{ }^{2-}$; the $\mathrm{CO}_{2}{ }^{*}$ represents the sum of $\mathrm{CO}_{2 \text { (aq) }}$ and $\mathrm{H}_{2} \mathrm{CO}_{3}$ because the latter is rapidly dissociated in seawater), which can be also referred, in some works, as $\mathrm{C}_{\mathrm{T}}, \mathrm{TIC}, \mathrm{TCO}_{2}$ or $\sum \mathrm{CO}_{2}$ (Zeebe, 2012). The equilibrium system of the DIC species on seawater is known as the marine carbonate system and is the main responsible to drive the buffer capacity of the ocean. Thus, the chemical species of the carbonate system in seawater changes to equilibrate the $\mathrm{H}^{+}$content, leaving the ocean with an average $\mathrm{pH}$ around 8.2 units (Zeebe and Wolf-Gladrow, 2001).

The intensification on the amount of $\mathrm{CO}_{2}$ in the atmosphere enhances the dissolution of this gas in the seawater, changing the $\mathrm{pH}$ of the oceans. The decrease of ocean $\mathrm{pH}$ due to the anthropogenic $\mathrm{CO}_{2}$ uptake is known as ocean acidification (OA), also presented as "the other $\mathrm{CO}_{2}$ problem" (Doney et al., 2009). Due to the current increase rate in atmospheric $\mathrm{CO}_{2}$ concentration, the mean $\mathrm{pH}$ on the surface waters has already decreased by 0.1 units since 1750 (Bindoff et al., 2007). In general, this 0.1 units decrease in $\mathrm{pH}$ could be considered a small and irrelevant change, however, this equals to $30 \%$ increase on the $\mathrm{H}^{+}$content in seawater, as $\mathrm{pH}$ corresponds to the inverse logarithm of $\mathrm{H}^{+}$ions activity. Moreover, with the continuous increase on the atmospheric $\mathrm{CO}_{2}$, it is predicted a decline in $\mathrm{pH}$ of around 0.3-0.4 units until 2100 (Meehl et al., 2007). The actual and predicted $\mathrm{pH}$ decrease will affect the ocean environment and its resources, impacting not only its biodiversity, but also food security and 


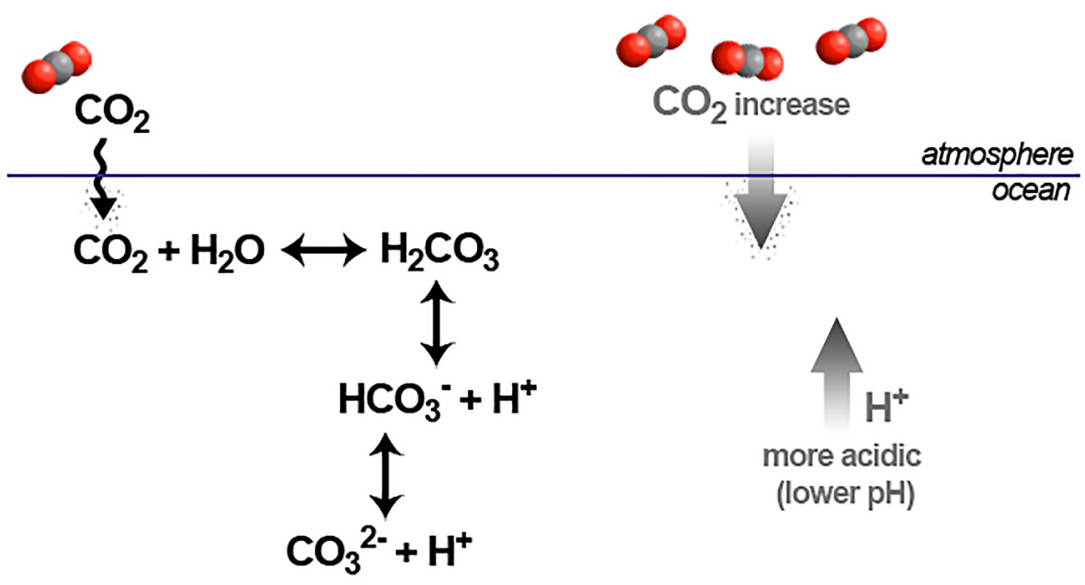

Figure 1. Marine carbonate system basic equilibrium. Schematic representation of the $\mathrm{CO}_{2}$ air-sea exchange and the basic equilibriums of the marine carbonate system in seawater.

economy of countries that rely on fisheries and aquaculture as an important source of income. Thus, it is essential to understand the perturbation of the $\mathrm{pH}$ change on the ocean and its several consequences.

The first OA studies have discussed mainly the changes in seawater biogeochemistry, followed by studies on the OA effects on different organisms (especially those with a calcium carbonate structure) and environments (e.g. Orr et al., 2005; Feely et al., 2004; Caldeira and Wickett, 2003; Kleypas et al., 1999; Brewer, 1997; Haugan and Drange, 1996; Broecker et al., 1979). However, despite the OA research increase on the first decades of the 21th century, there are some issues that remain unsolved (e.g. Browman, 2016; Yang et al., 2016), like the OA effects in organisms, ranging from negative to neutral (and even positive), and the multiple stressors studies difficulty, due to the combination of the several drivers as oxygen and temperature (Browman, 2016). It is also important to emphasize in OA studies the different responses that each ecosystem types may display in case of changes. For example, coastal shallow water areas will likely have their carbonate system strongly affected by changes in the biological processes like photosynthesis and remineralization (e.g. Waldbusser and Salisbury, 2014; Duarte et al., 2013; Andersson and Mackenzie, 2012; Feely et al., 2010).

The significant increase in the number of studies targeting OA has led to further thinking on the rapidly growing field of research (Riebesel and Gattuso, 2014), with the identification of the highest priorities for future investigations on the changing ocean (Newton et al., 2015). These goals are: (i) improve our understanding of the actual global OA state; (ii) improve our understanding of the ecosystem changes under the OA pressure; (iii) improve the models related to the OA and its impacts. Furthermore, the fast increase in the number of OA papers brought up some concerns about the data generated on these studies, one of them being data quality, which is direct related to the measurements precision (Newton et al., 2015). It is important to note that, analytically, the precision is related to the measurement repeatability, while the accuracy corresponds to the difference between a measurement and a "true" value. On this note, we follow the uncertainty definition by Newton et al. (2015), i.e. "it is the mean standard uncertainty of measurement, which that is with the associated confidence interval equivalent to that for a standard deviation".

Distinct purposes of research need to achieve different measurement quality goals. Studies regarding multidecadal time-series changes in an open ocean station will deal with a "signal to noise" relationship different from that observed in an estuarine system study (Newton et al., 2015). According to this requirement, the Global Ocean Acidification Observing Network (GOA-ON; www.goaon.org) has defined two quality criteria to be used in OA studies: weather and climate data; both defined in Newton et al. (2015). It is interesting to emphasize that these criteria are not related to the climatic science, despite their names, but are only a way to distinguish the quality of the acquired carbonate system data (e.g. Bockmon and Dickson, 2015). 
Weather data are those of "sufficient quality to identify relative spatial patterns and short-term variation", which supports interpretation of ecosystem response in dynamic studies. Climate data are those with "quality sufficient to assess long-term trends with a defined level of confidence", which is related to low dynamic studies, like changes in the hydrographic conditions in long-term studies. Thus, in a hypothetical case where it is necessary to obtain the $\mathrm{CO}_{3}{ }^{2-}$ concentration, one will need to have an uncertainty of $10 \%$ for weather data and $1 \%$ to climate data (Newton et al., 2015). However, despite of the data type, all results should be accompanied by: (i) the uncertainty of the obtained data (measured or estimated), (ii) the standard material and the equilibrium constants applied, and (iii) the units and scales. These results, weather or climate, can be submitted to the global databases, allowing knowledge improvement and comparison of the carbonate system variables processes. It is important to highlight that all studies also need to present four basic parameters: temperature, salinity, pressure (or water depth) and dissolved oxygen concentration, which are essential ocean variables. Fluorescence and irradiance are also important parameters and should be presented when available, since they may serve as primary production proxies (biological activity affects the carbonate system; Newton et al., 2015).

In general, studies concerning OA and the marine carbonate system usually evaluate only two of the six main variables to estimate the whole carbonate system parameters. This approach is known as "two out of six" strategy (Zeebe, 2012). This method is based in the fact that the whole carbonate system can be described by six main variables:DIC, total alkalinity (TA), $\left[\mathrm{CO}_{2}{ }^{*}\right],\left[\mathrm{HCO}_{3}^{-}\right]$, $\left[\mathrm{CO}_{3}{ }^{2-}\right]$ and $\left[\mathrm{H}^{+}\right]$. To the purposes of this note we will consider a simplified view of the variable TA, a measure of the difference between proton donors and acceptors in seawater, as presented by Zeebe (2012) (Equation 1). This simplification does not specify the minor components that can affect TA. These components are ions like $\mathrm{NH}_{4}^{+}, \mathrm{NO}_{3}$, $\mathrm{HPO}_{4}^{2-}$ or $\mathrm{H}_{3} \mathrm{SiO}_{4}^{-}$, which alter TA particularly in coastal and estuarine areas due to processes as denitrification and organic matter remineralization (Wolf-Gladrow et al., 2007).

All the six main carbonate system variables (DIC, TA, $\left[\mathrm{CO}_{2}{ }^{*}\right],\left[\mathrm{HCO}_{3}^{-}\right],\left[\mathrm{CO}_{3}^{2-}\right]$ and $\left.\left[\mathrm{H}^{+}\right]\right)$are in thermodynamic equilibrium and have known constants, which convey in a set of four equations and six unknown variables (Zeebe, 2012). Thus, if two variables of the system are known, like $\mathrm{pH}\left(\left[\mathrm{H}^{+}\right]\right)$and $\mathrm{DIC}$, the four equations can be solved to estimate the four unknown variables. To estimate the unknown variables of the carbonate system it is possible to use several specific open-source software packages (Orr et al., 2015). This approach encourages the study of the carbonate system, because it is not necessary to analytically determine each system variable. Moreover, the efforts to achieve quality measurements can be focused in only two variables.

$$
\begin{aligned}
& \mathrm{TA} \approx\left[\mathrm{HCO}_{3}^{-}\right]+2\left[\mathrm{CO}_{3}^{2-}\right]+\left[\mathrm{B}(\mathrm{OH})_{4}^{-}\right]+ \\
& {\left[\mathrm{OH}^{-}\right]-\left[\mathrm{H}^{+}\right]+[\text {minor components }]}
\end{aligned}
$$

The choice of the two variables to be analyzed will depend on the carbonate system parameters of interest on the study and on the analytical capacity of the laboratory (e.g. Bockmon and Dickson, 2015). The laboratory capability will rely on its competence to follow the recommended methods (Riebesell et al., 2011; Dickson et al., 2007; DOE, 1994) or, when using alternative methods, the evaluation of its reproducibility and accuracy according to international standards (Bockmon and Dickson, 2015). It is important to understand that the two variables chosen to estimate the unknown variable will directly affect the uncertainty attached to it (e.g. Millero, 2007). For example, pairing $\mathrm{pH}$ and $\mathrm{TA}$ to estimate $\left[\mathrm{CO}_{3}{ }^{2-}\right]$ leads to an uncertainty around $3.7 \%$, while when using DIC and TA it will be around $1.7 \%$ (based on the common uncertainty of the state of the art methodologies) (Dickson, 2011). Moreover, the techniques available to determine the marine carbonate system variables have different uncertainties attached to them. For example, the common techniques to determine $\mathrm{pH}$ on $\mathrm{OA}$ studies have uncertainties ranging from 0.003 to $0.01 \mathrm{pH}$ units (spectrophotometric determination using $\mathrm{m}$-cresol purple and potentiometric determination with standard Tris, respectively; both with certified reference material (CRM) calibration), while for TA it ranges from 1.2 to $10 \mu \mathrm{mol}$ $\mathrm{kg}^{-1}$ (closed and open cell titration, respectively; both with CRM calibration) (Dickson, 2011). The effect of these differences on the estimation of a variable like $\left[\mathrm{CO}_{3}{ }^{2-}\right]$ can change its final uncertainty to around $2 \%$ (Figure 2). However, it is important to emphasize that, on this example, the effect of the $\mathrm{pH}$ uncertainty on the $\left[\mathrm{CO}_{3}{ }^{2-}\right]$ estimation is stronger when compared to TA, as observed in Figure 2. Therefore, the choice of the variables that will be analyzed rely not only on the technical capability of the laboratory, including the sampling procedure, but also on the uncertainty that you need for the estimation of carbonate system variables. The final uncertainty of the carbonate 


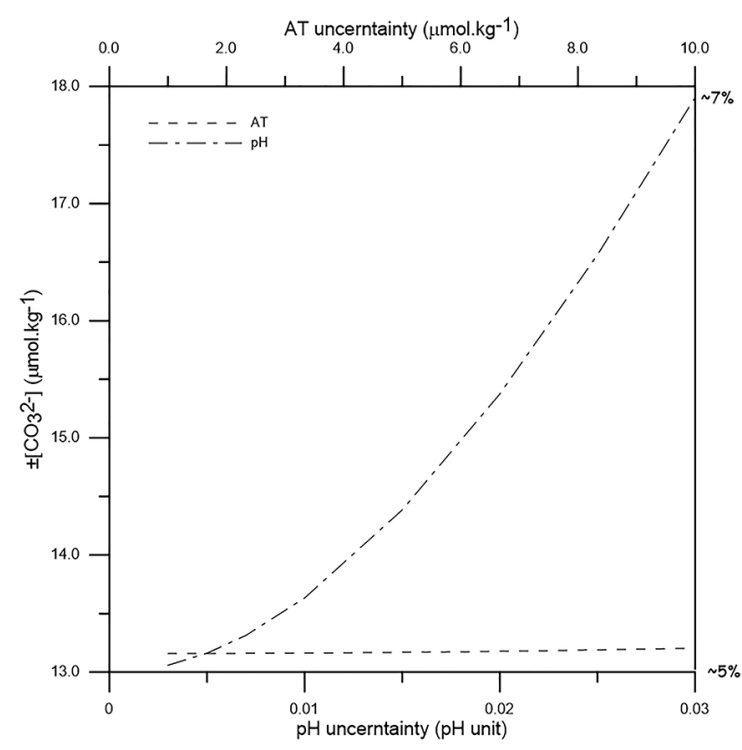

Figure 2. Final uncertainties differences according to carbonate parameters uncertainties. Changes on the estimated $\left[\mathrm{CO}_{3}{ }^{2-}\right]$ final uncertainty according to different $\mathrm{pH}$ and $\mathrm{AT}$ uncertainties (based on the values presented in Dickson, 2011). Calculated using CO2sys v2.2 and the hypothetical values: $\mathrm{S}=35, \mathrm{~T}=20^{\circ} \mathrm{C}$, [phosphate] $=$ $2 \mu \mathrm{mol} \mathrm{kg}{ }^{-1}$, [silicate] $=60 \mu \mathrm{mol} \mathrm{kg}{ }^{-1}, \mathrm{TA}=2300 \mu \mathrm{mol} \mathrm{kg}-1, \mathrm{pH}=$ 8.2 , with estimated $\left[\mathrm{CO}_{3}{ }^{2-}\right]=241 \mu \mathrm{mol} \mathrm{kg}{ }^{-1}$. The scales and constants chosen on software were: total $\mathrm{pH}$ scale; $\mathrm{K} 1$ and $\mathrm{K} 2$ from Lueker et al. (2000); KS from Dickson (1990) and KB from Uppström (1974). The uncertainties in constants applied to the software were: 0.004 for $\mathrm{pK} 0$; 0.015 for $\mathrm{pK} 1 ; 0.03$ for $\mathrm{pK} 2 ; 0.01$ for $\mathrm{pKb} ; 0.01$ for $\mathrm{pKw}$; 0.02 for $\mathrm{pKsp}$ aragonite and 0.02 for $\mathrm{pKsp}$ calcite (the choice of these values is based on personal communication to Orr, J.C.).

system estimated variables can be achieved using the error propagation technique (Gattuso et al., 2016).

The acceptable uncertainty on each study, climate or weather (Table 1), will depend on the purposes of each research. Long term studies in the open ocean surface, for example, have very small changes on $\mathrm{pH}$ through time, thus any slight variability needs to be precisely obtained. Therefore, when the variability of a parameter is restrained, it is necessary to achieve the lowest uncertainty possible (e.g., for a $\mathrm{pH}$ change of 0.005 units the uncertainty should be $<0.005$ ). In comparison, in eutrophic estuarine systems the $\mathrm{pH}$ may change several units within the tidal cycle (values ranging in general between 7 to $8 \mathrm{pH}$ units with the sea front entering/leaving the system), which allows the use of higher uncertainty techniques (e.g., for a $\mathrm{pH}$ change of 0.05 units the uncertainty could be $>0.005$, but not $<0.05$ ). It is important to emphasize that the values presented on Table 1 need to be considered carefully and as a guide. According to Bockmon and Dickson (2015), very few laboratories can achieve the climate uncertainties of Table 1 and could be worthwhile that the
OA community review the acceptable uncertainties to each goal. For example, in an inter-laboratory comparison more than half laboratories achieved a TA uncertainty of 5 $\mu$ mol kg-1 (Bockmon and Dickson, 2015) which is similar to the climate order of magnitude; however, according to Table 1 it still characterized as a weather data.

Recent initiatives are working to organize both regionally and globally the scientific community, to improve the compilation of data and the technical capacity. The GOA-ON initiative emphasizes the development of carbon observation networks in the international community, establishing methods and standards to be used by researchers. In Latin America, scientists from seven countries, including Brazil, established the LatinAmerican Ocean Acidification Network (LAOCA, www.laoca.cl) in 2015. Among the goals of LAOCA, it is important to highlight that: (i) standard analytical techniques need to be defined, enhancing quality data; and (ii) the commitment between the network members to make their results available in a database after two years from the end of the study.

The OA community is rapidly increasing in Brazil (Brazilian Ocean Acidification Network - BrOA; www. broa.furg.br), with studies from different research areas covering different parts of the Brazilian coastline, the open ocean areas and the western South Atlantic Ocean (e.g. Longuini et al., 2015; Cotovicz et al. 2016a; Kerr et al., 2016; Ito et al., 2016; Lencina-Avila et al., 2016; Orselli et al., 2018) and the Southern Ocean (e.g. Kerr et al., 2018a, 2018b; Lencina-Avila et al., 2018) (Table 2). The relevant increase in Brazilian OA publications in the last years emphasizes the importance of applying and publishing the estimation of uncertainties for the marine carbonate system variables, allowing the national research to achieve international quality standards and to contribute to global ocean databases such as SOCAT (Bakker et al., 2016) and GLODAP (Olsen et al., 2016). Thus, not only improving the knowledge concerning the $\mathrm{OA}$, but also increasing the visibility of Brazil in the international scientific community. It is evident, according to the last BrOA Network publication (Kerr et al., 2016), that the Brazilian OA community is improving the data quality and technical information, even considering the distinct approaches and ecosystems, which includes: evaluation of carbonate system parameters and/or acidification in rivers (Abril et al., 2014), estuaries (Cotovicz et al., 2015; Cotovicz et al. 2016b), lagoons (Peixoto et al., 2013), lakes (Marotta et al., 2014; Fontes et al., 2015) and open ocean 
Table 1. The uncertainties of the standard carbonate system parameters for each data quality goal, weather or climate, according to Newton et al. (2015).

\begin{tabular}{lcc}
\hline & \multicolumn{2}{c}{ Quality goals data } \\
\hline & weather & climate* \\
{$\left[\mathrm{CO}_{3}{ }^{2-}\right]$} & $10 \%$ & $1 \%$ \\
$\mathrm{pH}$ & $0.02 \mu \mathrm{units}$ & $0.003 \mathrm{units}$ \\
$\mathrm{TA}$ & $10 \mu \mathrm{mol} \mathrm{kg}^{-1}$ & $2 \mu \mathrm{mol} \mathrm{kg}^{-1}$ \\
$\mathrm{DIC}$ & $10 \mu \mathrm{mol} \mathrm{kg}^{-1}$ & $2 \mu \mathrm{mol} \mathrm{kg}^{-1}$ \\
$\mathrm{pCO}_{2}$ & $2.5 \%$ & $0.5 \%$ \\
\hline * the level of precision required is only achievable by limited laboratories and usually for some of the variables described here.
\end{tabular}

Table 2. Examples of marine carbonate system and OA studies executed by Brazilian research groups since the BrOA Network creation in 2012. The analyzed parameters, the weather/climate classification based on the precision of measurements, and the indication of use of certified reference materials (CRMs, as recommended in Dickson et al. 2007) are included. Figure 3 shows the geographical location of each study. Other studies can be accessed at www.broa.furg.br.

\begin{tabular}{|c|c|c|c|c|c|}
\hline Reference $n^{\circ}$. & Reference & Study area & Analyzed parameters (precision) & $\begin{array}{l}\text { Quality } \\
\text { level }^{\mathrm{a}}\end{array}$ & Use of CRMs \\
\hline 1 & Bonou et al. (2016) ${ }^{\mathrm{b}}$ & Tropical Atlantic & 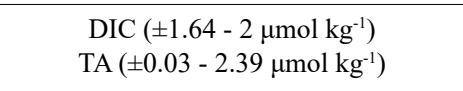 & Climate & Yes \\
\hline 2 & Bruto et al. (2017) & $\begin{array}{l}\text { NW Tropical } \\
\text { Atlantic }\end{array}$ & $\mathrm{fCO}_{2}( \pm 3 \mu \mathrm{atm})$ & Climate & $\begin{array}{l}\text { CARIOCA } \\
\text { sensor }\end{array}$ \\
\hline 3 & $\begin{array}{l}\text { Cotovicz Jr et al. } \\
\text { (2015) }\end{array}$ & SE Brazil & $\begin{array}{c}\mathrm{pCO}_{2}( \pm 3.0 \mathrm{ppmv}) \\
\mathrm{TA}( \pm 3 \mu \mathrm{mol} \mathrm{kg}-1) \\
\mathrm{pH}( \pm 0.01)\end{array}$ & $\begin{array}{l}\text { Climate/ } \\
\text { Weather }\end{array}$ & Yes \\
\hline 4 & $\begin{array}{l}\text { Cotovicz Jr et al. } \\
\qquad(2016 \mathrm{~b})\end{array}$ & SE and NE Brazil & $\begin{array}{l}\mathrm{TA}\left( \pm 3 \mu \mathrm{mol} \mathrm{kg}{ }^{-1}\right) \\
\mathrm{pCO}_{2}( \pm 3.0 \mathrm{ppmv}) \\
\mathrm{pH}( \pm 0.01)\end{array}$ & $\begin{array}{l}\text { Climate/ } \\
\text { Weather }\end{array}$ & Yes \\
\hline 5 & Guenther et al. (2017) & NE Brazil & $\begin{array}{c}\mathrm{pH}( \pm 0.005) \\
\mathrm{TA}\left( \pm 10 \mu \mathrm{mol} \mathrm{kg}^{-1}\right)\end{array}$ & Weather* & No \\
\hline 6 & Ito et al. (2016) & SW South Atlantic & $\begin{array}{c}\mathrm{pCO}_{2} \text { seawater }( \pm 0.3 \mu \mathrm{atm}) \\
\mathrm{pCO}_{2} \text { air }( \pm 0.1 \mu \mathrm{atm})\end{array}$ & Climate & No \\
\hline 7 & Kerr et al. (2018a) & Southern Ocean & $\begin{array}{c}\text { DIC }\left( \pm 5 \mu \mathrm{mol} \mathrm{kg} \mathrm{kg}^{-1}\right) \\
\text { TA }\left( \pm 3 \mu \mathrm{mol} \mathrm{kg}^{-1}\right)\end{array}$ & Weather* & Yes \\
\hline 8 & Kerr et al. (2018b) & Southern Ocean & $\begin{array}{c}\mathrm{DIC}\left( \pm 5 \mu \mathrm{mol} \mathrm{kg} \mathrm{kg}^{-1}\right) \\
\mathrm{TA}\left( \pm 3 \mu \mathrm{mol} \mathrm{kg}^{-1}\right)\end{array}$ & Weather* & Yes \\
\hline 9 & $\begin{array}{l}\text { Lencina-Avila et al. } \\
\qquad(2016)\end{array}$ & South Atlantic & $\mathrm{pCO}_{2}( \pm 0.6-0.9 \%)$ & Climate & Yes \\
\hline 10 & $\begin{array}{l}\text { Lencina-Avila et al. } \\
\qquad(2018)^{\circ}\end{array}$ & Southern Ocean & $\begin{array}{c}\text { TA (ranging from not } \\
\text { informed to } \pm 4.4 \mu \mathrm{mol} \mathrm{kg}{ }^{-1} \text { ) } \\
\text { DIC (ranging from } 2.7 \text { to } \pm 5.6 \mu \mathrm{mol} \mathrm{kg}^{-1} \text { ) }\end{array}$ & $\begin{array}{l}\text { Climate } \\
\text { /Weather* }\end{array}$ & Yes \\
\hline 11 & Longhini et al. (2015) & NE Brazil & $\begin{array}{l}\mathrm{pH}( \pm 0.01) \\
\mathrm{TA}( \pm 5 \mu \mathrm{M})\end{array}$ & Weather* & Yes \\
\hline 12 & $\begin{array}{l}\text { Noriega \& Araujo } \\
\quad(2014)\end{array}$ & $\begin{array}{l}\mathrm{N} \text { and NE Brazil - } \\
\text { estuaries }\end{array}$ & $\begin{array}{c}\mathrm{pH}( \pm 0.005) \\
\mathrm{TA}\left( \pm 20 \mu \mathrm{mol} \mathrm{kg}^{-1}\right)\end{array}$ & Weather* & No \\
\hline 13 & Noriega et al. (2015) & $\begin{array}{l}\text { NE Brazil - } \\
\text { estuaries }\end{array}$ & $\begin{array}{c}\mathrm{pH}( \pm 0.005) \\
\mathrm{TA}\left( \pm 20 \mu \mathrm{mol} \mathrm{kg}^{-1}\right)\end{array}$ & Weather* & No \\
\hline 14 & Orselli et al. (2018) & SW Atlantic & $\begin{array}{c}\mathrm{DIC}\left( \pm 4.0 \mu \mathrm{mol} \mathrm{kg} \mathrm{kg}^{-1}\right) \\
\mathrm{TA}\left( \pm 2.3 \mu \mathrm{mol} \mathrm{kg}{ }^{-1}\right)\end{array}$ & $\begin{array}{l}\text { Climate/ } \\
\text { Weather* }\end{array}$ & Yes \\
\hline
\end{tabular}

a The quality level on this Table was defined according to Table 1 . The character * indicates the data that is closer to climate than weather goal, but still characterized as weather.

${ }^{\mathrm{b}}$ Bonou et al. (2016) used an historical dataset from 35 available cruises executed in the Western Tropical Atlantic from 1989 to 2014. So, distinct methods with distinct precisions were used.

${ }^{c}$ Lencina-Avila et al. (2018) reconstructed the carbonate system parameters from hydrographic data obtained in the study region (e.g. Mata and Kerr, 2016a, 2016b; Azaneu et al., 2013; Dotto et al., 2016; Kerr et al., 2018a, 2018b; Lencina-Avila et al., under review). The marine carbonate system parameters were measured for years 2015 and 2016. 
areas (Ito et al., 2016; Orselli et al., 2018); studies of the impact of OA and other stressors in marine biota (Garrard et al., 2013; Rodríguez-Romero et al., 2014; Goulding et al. 2017); and laboratory experiments (Orte et al., 2014; Scherner, et al., 2016; Schneider et al., 2018). Some examples of the BrOA studies done in the last five years associated with their classification based on the method precision are summarized in Table 2 and Figure 3. The members of BrOA Network have also been involved in OA best practices measurements discussions and workshops, increasing the number of researchers committed to the dissemination and use of best analytical practices to determine the parameters of the marine carbonate system. This is important to place the Brazilian OA studies in an international scenario, as well as to fill a gap of unknown information about the Tropical and South Atlantic OA oceanographic processes with a desirable quality.

\section{ACKNOWLEDGEMENTS}

This note provides a contribution to the activities of the Brazilian Ocean Acidification Network (BrOA; www. broa.furg.br, contact e-mail: broa@furg.br). We want to acknowledge the sponsors (The International Ocean Carbon Coordination Project, IOCCP and the International Atomic Energy Agency, IAEA) and co-sponsorship (Millennium Institute of Oceanography, IMO and the Center for the Study of Multiple-Drivers on Marine Socio-Ecological Systems, MUSELS) of the $1^{\text {st }}$ Technical Workshop on Ocean Acidification Measurements for the LAOCA; also the lecturers and attendants of the event for providing the opportunity for the discussion of the technical aspects of the analytical methods to determine the variables of the marine carbonate system. $\mathrm{R}$. Kerr acknowledges CNPq researcher grant no 302604/2015-4. We thank two anonymous reviewers for their comments and suggestions, which greatly improved this letter.

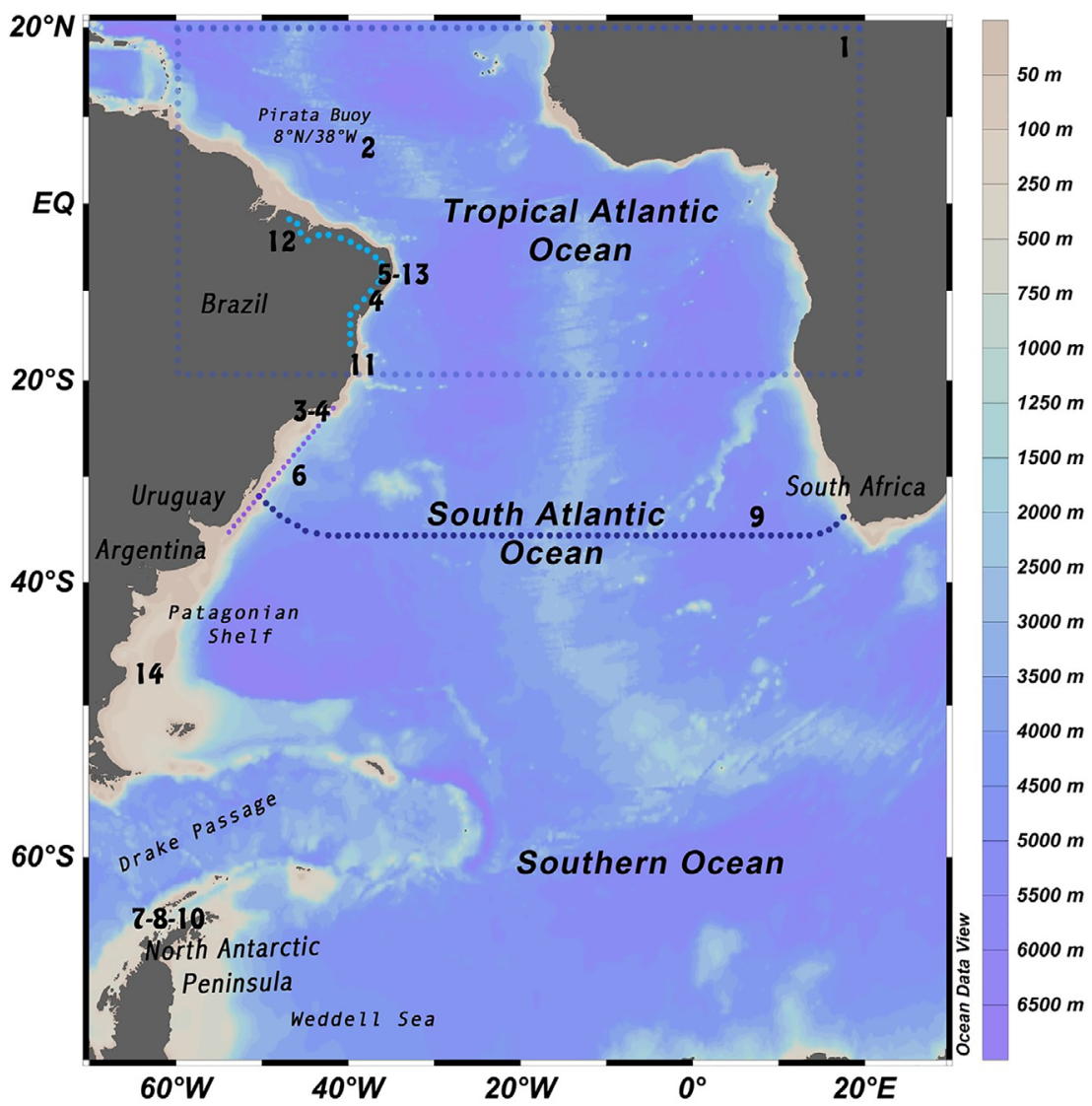

Figure 3. Map indicating the study area of the works from Table 2. Map of the tropical and south Atlantic, including the Atlantic sector of the Southern Ocean. The numbers indicate the references cited in the table 2. The different dotted lines delimit study areas or transects of the references. Light blue: Bonou et al. (2016); blue: Noriega \& Araujo (2014); dark blue: Lencina-Avila et al. (2016); purple: Ito et al. (2016). 


\section{REFERENCES}

ABRIL, G., MARTINEZ, J., ARTIGAS, L. F., MOREIRA-TURCQ, P., BENEDETTI, M. F., VIDAL, L., MEZIANE, T., KIM, J., BERNARDES, M. C., SAVOYE, N., DEBORDE, J., SOUZA, E. L., ALBÉRIC, P., SOUZA, M. F. L. \& ROLAND, F. 2014. Amazon River carbon dioxide outgassing fuelled by wetlands. Nature, 505, 395-398.

ANDERSSON, A. J. \& MACKENZIE, F. T. 2012. Revisiting four scientific debates in ocean acidification research. Biogeosciences, 9, 893-905.

BAKKER, D. C. E., PFEIL, B., LANDA, C. S., METZI, N., O'BRIEN, K. M., OLSEN, A., NOJIRI, Y., SCHUSTER, U., STEINHOFF, T., SWEENEY, C., TAKAHASHI, T., TILBROOK, B., WADA, C., WANNINKHOF, R., ALIN, S. R., BALESTRINI, C. F., BARBERO, L., BATES, N. R., BIANCHI, A. A., BONOU, F., BOUTIN, J., BOZEC, Y., BURGER, E. F., CAI, W. J., CASTLE, R. D., CHEN, L., MELISSA, C., CURRIE, K., EVANS, W., FEATHERSTONE, C., FEELY, R. A., FRANSSON, A., GOYET, C., GREENWOOD, N., GREGOR, L., HANKIN, S., HARDMAN-MOUNTFORD, N. J., HARLAY, J., HAUCK, J., HOPPEMA, M., HUMPHREYS, M. P., HUNT, C. W., HUSS, B., IBANHEZ, S. P., JOHANSSEN, T., KEELING, R., KITIDIS, V., KÖRTZINGER, A., KOZYR, A., KRASAKOPOULOU, E., KUWATA, A., LANDSCHÜTZER, P., LAUVSET, S. K., LEFÈVRE, N., MONACO, C. L., MANKE, A., MATHIS, J. T., MERLIVAT, L., MILLERO, F .J., MONTEIRO, P. M. S., MUNRO, D. R., MURATA, A., NEWBERGER, T., OMAR, A. M., ONU, T., PATERSON, K., PEARCE, D., PIERRTO, D., ROBINS, L. L., SAITO, S., SALISBURY, J., SCHILTZER, R., SCHNEIDER, B., SCHWETZER, R., SIEGER, R., SKJELVAN, I., SULLIVAN, K. F., SUTHERLAND, S. C., SUTTON, A. J., TADOKORO, K., TELSZEWSKI, M., TUMA, M., VAN HEUVEN, S. M. A. C., WARD, B., WATSON, A. J. \& XU, S. 2016. A multi-decade record of high-quality $\mathrm{fCO}_{2}$ data in version 3 of the Surface Ocean $\mathrm{CO}_{2}$ Atlas (SOCAT). Earth System Science Data, 8, 383-413.

BINDOFF, N. L., WILLEBRAND, J., ARTALE, V., CAZENAVE, A., GREGORY, J. M., GULEV, S., HANAWA, K., LE QUÉRÉ, C., LEVITUS, S., NOJIRI, Y., SHUM, C. K., TALLEY, L. D. \& UNNIKRISHNAN, A. S. 2007. Observations: Oceanic climate change and sea level. In: SOLOMON, S., QIN, D., MANNING, M., MARQUIS, M., AVERYT, K. B., TIGNOR, M., MILLER, H. L. \& CHEN, Z. (eds.) Climate Change 2007: The Physical Science Basis. Contribution of Working Group I to the Fourth Assessment Report of the Intergovernmental Panel of Climate Change. Cambridge (UK) and New York (USA): Cambridge University Press.

BOCKMON, E. E. \& DICKSON, A. G. 2015. An inter-laboratory comparison assessing the quality of seawater carbon dioxide measurements. Marine Chemistry, 171, 36-43.

BONOU, F. K., NORIEGA, C., LEFÉVRE, N. \& ARAUJO, M. 2016. Distribution of $\mathrm{CO}_{2}$ parameters in the Western Tropical Atlantic Ocean. Dynamics of Atmospheres and Oceans, 73, 47-60.

BREWER, P. G. 1997. Ocean chemistry of the fossil fuel $\mathrm{CO}_{2}$ signal: The haline signal of "business as usual". Geophysical Research Letters, 24, 1367-1369.

BROECKER, W. S., TAKAHASHI. T., SIMPSON, H. J. \& PENG, T. H. 1979. Fate of fossil fuel carbon dioxide and the global carbon budget. Science, 206, 409-418.
BROWMAN, H. I. 2016. Applying organized scepticism to ocean acidification research. ICES Journal of Marine Science, 73, 529-536.

BRUTO, L., ARAUJO, M., NORIEGA, C., VELEDA, D. \& LEFÉVRE, N. 2017. Variability of $\mathrm{CO}_{2}$ fugacity at the western edge of the tropical Atlantic Ocean from the $8^{\circ} \mathrm{N}$ to $38^{\circ} \mathrm{W}$ PIRATA buoy. Dynamics of Atmospheres and Oceans, 78, 1-13.

CALDEIRA, K. \& WICKETT, M. E. 2003. Oceanography: Anthropogenic carbon and ocean $\mathrm{pH}$. Nature, 425, 365.

CIAIS, P., SABINE, C., GOVINDASAMY, B., BOPP, L., BROVKIN, V., CANADELL, J., CHHABRA, A., DEFRIES, R., GALLOWAY, J., HEIMANN, M., JONES, C., LE QUÉRÉ, C., MYNENI, R., PIAO, S. \& THORNTON, P. 2013. Carbon and Other Biogeochemical Cycles. In: STOCKER, T., QIN, D. \& PLATNER, G. K. (eds.) Climate Change 2013: The Physical Science Basis. Working Group I contribution to the Fifth Assessment Report of the Intergovernmental Panel of Climate Change. Cambridge (UK) and New York (USA): Cambridge University Press.

COTOVICZ JR, L. C., KNOPPERS, B. A., BRANDINI, N., COSTA SANTOS, S. J. \& ABRIL, G. 2015. A strong $\mathrm{CO}_{2}$ sink enhanced by eutrophication in a tropical coastal embayment (Guanabara Bay, Rio de Janeiro, Brazil). Biogeosciences, 12, 6125-6146.

COTOVICZ JR, L. C., KNOPPERS, B. A., BRANDINI, N., POIRIER, D., COSTA SANTOS, S. J. \& ABRIL, G. 2016a. Spatio-temporal variability of methane $\left(\mathrm{CH}_{4}\right)$ concentrations and diffusive fluxes from a tropical coastal embayment surrounded by a large urban area (Guanabara Bay, Rio de Janeiro, Brazil). Limnology and Oceanography, 61, S238-S252.

COTOVICZ JR, L. C., LIBARDONI, B. G., BRANDINI, N., KNOPPERS, B. A. \& ABRIL, G. 2016b. Comparações entre medições e tempo real da $p \mathrm{CO}_{2}$ aquática com estimativas indiretas em dois estuários tropicais contrastantes: o estuário eutrofizado da Baia de Guanabara e o estuário oligotrófico do rio são Francisco (AL). Química Nova, 39, 1206-1214.

DICKSON, A. G. 2011. The carbon dioxide system in seawater: equilibrium chemistry and measurements. In: RIEBESELL, U., FABRY, V. J., HANSSON, L. \& GATTUSO, J. P. (eds.) Guide to best practices for ocean acidification research and data reporting. Luxembourg: Publications Office of the European Union.

DICKSON, A. G., SABINE, C. L. \& CHRISTIAN, J. R. 2007. Guide to Best Practices for Ocean $\mathrm{CO}_{2}$ Measurements. Sidney (BC): PICES Special Publication 3.

DOE, DICKSON, A. G. \& GOYET, C. (eds.) 1994. Handbook of methods for the analysis of the various parameters of the carbon dioxide system in sea water; version 2. Washington: ORNL/CDIAC-74, Oak Ridge, USA.

DONEY, S. C., FABRY, V. J., FEELEY, R. A. \& KLEYPAS, J. A. 2009. Ocean acidification: The other $\mathrm{CO}_{2}$ problem. Annual Review of Marine Science, 1, 169-192.

DUARTE, C. M., HENDRIKS, I. E., MOORE, T. S., OLSEN, Y. S., STECKBAUER, A., RAMAJO, L., CARSTENSEN, J., TROTTER, J. A. \& MCCULLOCH, M. 2013. Is Ocean Acidification an Open-Ocean Syndrome? Understanding Anthropogenic Impacts on Seawater pH. Estuaries and Coasts, 36, 221-236.

FEELY, R. A., SABINE, C. L., LEE, K., BERELSON, W., KLEYPAS, J., FABRY, V. J. \& MILLERO, F. J. 2004. Impact of Anthropogenic $\mathrm{CO}_{2}$ on the $\mathrm{CaCO}_{3}$ System in the Oceans. Science, 305, 362-366. 
FEELY, R. A., ALIN, S. R., NEWTON, J., SABINE, C. L., WARNER, M., DEVOL, A., KREMBS, C. \& MALOY, C. 2010. The combined effects of ocean acidification, mixing, and respiration on $\mathrm{pH}$ and carbonate saturation in an urbanized estuary. Estuarine, Coastal and Shelf Science, 88, 442-449.

FONTES, M. L. S., MAROTTA, H., MACINTYRE, S. \& PETRUCIO, M. M. 2015. Inter- and intra-annual variations of $\mathrm{pCO}_{2}$ and $\mathrm{pO}_{2}$ in a freshwater subtropical coastal lake. Inland Waters, 5, 107-116.

GARRARD, S. L., HUNTER, R. C., FROMEL, A. Y., LANE, A. C., PHILLIPS, J. C., COOPER, R., DINESHRAM, R., CARDINI, U., MCCOY, S. J., ARNBERG, M., RODRIGUES ALVES, B. G., ANNANE, S., ORTE, M. R., KUMAR, A., AGUIRRE-MARTINEZ, G. V., MANEJA, R. H., BASALLOTE, M. D., APE, F., TORSTENSSON, A. \& BJOERK, M. M. 2013. Biological impacts of ocean acidification: a postgraduate perspective on research priorities. Marine Biology, 160, 1789-1805.

GATTUSO, J. P., EPITALON, J. M., LAVIGNE, H., ORR, J., GENTILI, B., HOFMANN, A., PROYE, A., SOETAERT, K. \& RAE, J. 2016. Calculates parameters of the seawater carbonate system and assists the design of ocean acidification perturbation experiments. Available from: https://cran.r-project.org/web/packages/seacarb/ index.html (last access: 26 Apr 2017).

GOULDING, T. A., ORTE, M. R., SZALAJ, D., BASALLOTE, M. S., DELVALLS, T. A. \& CESAR, A. 2017. Assessment of the environmental impacts of ocean acidification (OA) and carbon capture and storage (CCS) leaks using the amphipod Hyale youngi. Ecotoxicology, 26, 521-533.

GUENTHER, M., ARAÚJO, M., NORIEGA, C., FLORES-MONTES, M., GONZALEZ-RODRIGUES, E. \& NEUMANN-LEITÃO, S. 2017. Plankton carbon metabolism and air-water $\mathrm{CO}_{2}$ fluxes at a hypereutrophic tropical estuary. Marine Ecology, 38, 1-12.

HAUGAN, P. M. \& DRANGE, H. 1996. Effects of $\mathrm{CO}_{2}$ on the ocean environment. Energy Conversion and Management, 37, 1019-1022.

ITO, R. G., GARCIA, C. A. E. \& TAVANO, V. M. 2016. Net sea-air $\mathrm{CO}_{2}$ fluxes and modelled $\mathrm{pCO}_{2}$ in the southwestern subtropical Atlantic continental shelf during spring 2010 and summer 2011. Continental Shelf Research, 119, 68-84.

KERR, R., DA CUNHA, L. C., KIKUCHI, R. K., HORTA, P. A., ITO, R. G., MÜLLER, M. N., ORSELLI, I. B., LENCINA-AVILA, J. M., DE ORTE, M. R., SORDO, L., PINHEIRO, B. SCHUBERT, N. R., BONOU, F. K., BERGSTROM, E. \& COPERTINO, M. S. 2016. The Western South Atlantic Ocean in a high $\mathrm{CO}_{2}$ world: Current measurements capabilities and perspectives. Environmental Management, 57, 740-752.

KERR, R., ORSELLI, I. B. M., LENCINA-AVILA, J. M., EIDT, R. T., MENDES, C. R. B., CUNHA, L. C., GOYET, C., MATA, M. M. \& TAVANO, V. M. 2018a. Carbonate system properties in the Gerlache Strait, Northern Antarctic Peninsula (February 2015): I. Sea-Air $\mathrm{CO}_{2}$ fluxes. Deep Sea Research Part II: Topical Studies in Oceanography. 149, 171-181.

KERR, R., GOYET, C., CUNHA, L. C., ORSELLI, I. B. M., LENCINA-AVILA, J. M., MENDES, C. R. B., CARVALHOBORGES, M., MATA, M. M. \& TAVANO, V. M. 2018b. Carbonate system properties in the Gerlache Strait, Northern Antarctic Peninsula (February 2015): II. Anthropogenic $\mathrm{CO}_{2}$ and seawater acidification. Deep Sea Research Part II: Topical Studies in Oceanography. 149, 182-192.
KLEYPAS, J. A., BUDDEMEIER, R. W., ARCHER, D., GATTUSO, J. P., LANGDON, C. \& OPDYKE, B. N. 1999. Geochemical consequences of increased atmospheric carbon dioxide on coral reefs. Science, 284, 118-120.

LE QUÉRÉ, C. ANDREW, R. B., CANADELL, G. J., SITCH, S., KORSBAKKEN, J. I., PETERS, G. P., MANNING, A. C., BODEN, T. A., TANS, P. P., HOUGHTON, R. A., KEELING, R. F., ALIN, S., ANDREWS, O. D., ANTHONI, P., BARBERO, L., BOPP, L., CHEVALLIER, F., CHINI, L. P., CIAIS, P., CURRIE, K., DELIRE, C., DONEY, S. C., FRIEDLINGSTEIN, P., GKRITZALIS, T., HARRIS, I., HAUCK, J., HAVERD, V., HOPPEMA, M., KLEIN GOLDEWIJK, K., JAIN, A. K., KATO, E., KÖRTZINGER, A., LANDSCHÜTZER, P., LEFÈVRE, N., LENTON, A., LIENERT, D., LOMBARDOZZI, D., MELTON, J. R., METZL, N., MILLERO, F., MONTEIRO, P. M. S., MUNRO, D. R., NABEL, J. E. M. S., NAKAOKA, S. I., O'BRIEN, K., OLSEN, A., OMAR, A. M., ONO, T., PIERROT, D., POULTER, B., RÖDENBECK, C., SALISBURY, J., SCHUSTER, U., SCHWINGER, J., SÉFÉRIAN, R., SKJELVAN, I., STOCKER, B. D., SUTTON, A. J., TAKAHASHI, T., TIAN, H., TILBROOK, B., VAN DER LAAN-LUIJKX, I. T., VAN DER WERF, G. R., VIOVY, N., WALKER, A. P., WILTSHIRE, A. J. \& ZAEHLE, S. 2016. Global carbon budget 2016. Earth System Science Data, 8, 605-649.

LENCINA-AVILA, J. M., ITO, R. G., GARCIA, C. A. E. \& TAVANO, V. M. 2016. Sea-air carbon dioxide fluxes along $35^{\circ} \mathrm{S}$ in the South Atlantic Ocean. Deep Sea Research Part I: Oceanographic Research Papers, 115, 175-187.

LENCINA-AVILA, J. M., GOYET, C., KERR, R., ORSELLI, I. B. M., MATA, M. M. M. \& TOURATIER, F. 2018. Past and future evolution of the carbonate system in a coastal zone of the Northern Antarctic Peninsula. Deep Sea Research Part II: Topical Studies in Oceanography. 149, 193-205.

LONGUINI, C. M. SOUZA, M. F. L. \& SILVA, A. M. 2015. Net ecosystem production, calcification and $\mathrm{CO}_{2}$ fluxes on a reef flat in Northeastern Brazil. Estuarine, Coastal and Shelf Science, 166, 13-23.

MAROTTA, H., PINHO, L., GUDASZ, C., BASTVIKEN, D., TRANVIK, L. J. \& ENRICH-PRAST, A. 2014. Greenhouse gas production in low-latitude lake sediments responds strongly to warming. Nature Climate Change, 4, 467-470.

MEEHL, G.A., STOCKER, T. F., COLLINS, W. D., FRIEDLINGSTEIN, P., GAYE, A. T., GREGORY, J. M., KITOH, A., KNUTTI, R., MURPHY, J. M., NODA, A., RAPER, S. B. C., WATTERSON, I. G., WEAVER, A. J. \& ZHAO, Z. C. 2007. Global climate projections. In: SOLOMON, S., QIN, D., MANNING, M., MARQUIS, M., AVERYT, K. B., TIGNOR, M., MILLER, H. L. \& CHEN, Z. (eds.) Climate Change 2007: The Physical Science Basis. Contribution of Working Group I to the Fourth Assessment Report of the Intergovernmental Panel of Climate Change. Cambridge (UK) and New York (USA): Cambridge University Press.

MILLERO, F. J. 2007. The Marine Inorganic Carbon Cycle. Chemical Reviews, 107, 308-341.

NEWTON, J. A., FEELY, R. A., JEWETT, E. B., WILLIAMSON, P. \& MATHIS, J. 2015. Global Ocean Acidification Observing Network (GOA-ON): Requirements and Governance Plan. $2^{\text {nd }}$. Available from: https://www.iaea.org/ocean-acidification/ page.php?page $=2200$ (last access: 28 May 2018). 
NORIEGA, C. \& ARAUJO, M. 2014. Carbon dioxide emissions from estuaries of northern and northeastern Brazil. Scientific Reports, 4, 6164.

NORIEGA, C., ARAUJO, M., LEFÈVRE, N., MONTES, M. F., GASPAR, F. \& VELEDA, D. 2015. Spatial and temporal variability of $\mathrm{CO}_{2}$ fluxes in tropical estuarine systems near areas of high population density in Brazil. Regional Environmental Change, 15, 619-630.

OLSEN, A. KEY, R. M., VAN HEUVEN, S., LAUVSET, S. K., VELO, A., LIN, X., SCHIRNICK, C., KOZYR, A., TANHUA, T., HOPPEMA, M., JUTTERSTRÖM, S., STEINFIELD, R., JEANSSON, E., ISHII, M., PÉREZ, F. F. \& SUZUKI, I. 2016. The Global Ocean Data Analysis Project version 2 (GLODAPv2) - an internally consistent data product for the world ocean. Earth System Science Data, 8, 297-323.

ORR, J. C., FABRY, V. J., AUMONT, O., BOPP, L., DONEY, S. C., FEELY, R. A., GNANADESIKAN, A., GRUBER, N., ISHIDA, A., JOOS, F., KEY, R. M., LINDSAY, K., MAIERREIMER, E., MATEAR, R., MONFRAY, P., MOUCHET, A., NAJJAR, R. G., PLATTNER, G. K., RODGERS, K. B., SABINE, C. L., SARMIENTO, J. L., SCHLITZER, R., SLATER, R. D., TOTTERDELL, I. J., WEIRIG, M. F., YAMANAKA, Y. \& YOOL, A. 2005. Anthropogenic ocean acidification over the twenty-first century and its impact on calcifying organisms. Nature, 437, 681-686.

ORR, J. C., EPITALION, J. M. \& GATTUSO, J. P. 2015. Comparison of ten packages that compute ocean carbonate chemistry. Biogeosciences, 12, 1483-1510.

ORSELLI, I. B. M., KERR, R., ITO, R. G., TAVANO, V. M., MENDES, C. R. \& GARCIA, C. A. E. 2018. How fast is the Patagonian shelf-break acidifying? Journal of Marine Systems, 178, 1-14.

ORTE, M. R., SARMIENTO, A. M., BASALLOTE, M. D., RODRÍGUEZ-ROMERO, A., RIBA, I. \& DELVALLS, A. 2014. Effects on the mobility of metals from acidification caused by possible $\mathrm{CO}_{2}$ leakage from sub-seabed geological formations. Science of the Total Environment, 470-471, 356-363.

PEIXOTO, R. B., MAROTTA, H. \& ENRICH-PRAST, A. 2013. Experimental evidence of nitrogen control on $\mathrm{pCO}_{2}$ in phosphorus-enriched humic and clear coastal lagoon waters. Frontiers in Microbiology, 4, 1-6.
RIEBESELL, U., FABRY, V. J., HANSSON, L. \& GATTUSO, J. P. 2011. Guide to best practices for ocean acidification research and data reporting, Luxembourg: Publications Office of the European Union.

RODRÍGUEZ-ROMERO, A. M. D., BASALLOTE, M. D., ORTE, M. R., DELVALSS, T. A., RIBA, I. \& BLASCO, J. 2014. Simulation of $\mathrm{CO}_{2}$ leakages during injection and storage in subseabed geological formations: Metal mobilization and biota effects. Environment International, 68, 105-117.

SABINE, C. L. \& TANHUA, T. 2010. Estimation of anthropogenic $\mathrm{CO}_{2}$ inventories in the ocean. Annual Review of Marine Science, 2, 175-198.

SCHERNER, F., PEREIRA, C. M., DUARTE, G., HORTA, P. A., E CASTRO, C. B., BARUFI, J. B. \& PEREIRA, S. M. B. 2016. Effects of Ocean Acidification and Temperature Increases on the Photosynthesis of Tropical Reef Calcified Macroalgae. PLoS One, 11, e 0154844.

SCHNEIDER, G., HORTA, P. A., CALDERON, E. N., CASTRO, C., BIANCHINI, A., DA SILVA, C. R. A., BRANDALISE, I., BARUFI, J. B., SILVA, J. \& RODRIGUES, A. C. 2018. Structural and physiological responses of Halodule wrightii to ocean acidification. Protoplasma, 255, 629-641.

WALDBUSSER, G. G. \& SALISBURY, J. E. 2014. Ocean acidification in the coastal zone from an organism's perspective: multiple system parameters, frequency domains, and habitats. Annual Review of Marine Science, 6, 221-247.

WOLF-GLADROW, D. A., ZEEBE, R. E., KLAAS, C., KÖRTZINGER, A. \& DICKSON, A. G. 2007. Total alkalinity: The explicit conservative expression and its application to biogeochemical processes. Marine Chemistry, 106, 287-300.

YANG, Y. F., HANSSON, L. \& GATTUSO, J. P. 2016. Data compilation on the biological response to ocean acidification: an update. Earth System Science Data, 8, 79-87.

ZEEBE, R. E. 2012. History of seawater carbonate chemistry, atmospheric $\mathrm{CO}_{2}$, and ocean acidification. Annual Review of Earth Planetary Science, 40, 141-165.

ZEEBE, R. E. \& WOLF-GLADROW, D. A., 2001. $\mathrm{CO}_{2}$ in Seawater: Equilibrium, Kinetics, Isotopes, Amsterdam, Elsevier Science. 